Vol. 4, No. 2, 2019

\title{
SOLAR POWER STATION \\ AS A “GREEN KEY” CERTIFICATION FACTOR
}

\section{Gabriela Klyn, Zoryana Odnorih, Myroslav Malovanyy, Maryan Svidovyy}

\author{
Lviv Polytechnic National University, \\ 12, S. Bandery Str., Lviv, 79013, Ukraine \\ gobika4567@gmail.com,odnorigzor@gmail.com, \\ mmal@lp.edu.ua,m.svidovy@gmail.com
}

https://doi.org/10.23939/ep2019.02.097

Received: 23.05.2019

() Klyn G., Odnorih Z., Malovanyy M., Svidovyy M., 2019

\begin{abstract}
The analysis of the negative impact of classical tourism on the environment elements is made. The generalized criteria for the eco-hotel and the environmental certification requirements of the Green Key Global Hotels are given. The calculation and selection of component parts of the network power station for the Derenivska Kupil apartment-hotel were carried out. The energy efficiency of the proposed solution is proven.
\end{abstract}

Key words: renewable energy; network solar power station; ecocertification; ecotourism.

\section{Introduction}

Changes in the biosphere because of intensive anthropogenic influence lead to imbalance of processes in any ecosystem and rapid exhaustion of natural resources. The consequences [1] which are responsible for reducing the biodiversity include destabilization of the ecosystem, weakening its ability to self restoration and reduction of productivity; decrease in the function of soil formation and greenhouse gases adsorption.

The possibility to choose ecological useful products, vehicles that are clear for the environment, the use of recycled materials and renewable energy sources in everyday life become widely popular with every human. Due to the use of renewable sources (sunlight, wind, sea tides and geothermal heat) it is possible to receive energy from the natural environment continuously and effectively without negative effect on the processes in the biosphere. Solar energy is one of such renewable energy sources. Every second the surface of the Earth receives 95.8 trillion watts of energy. For many years, numerous devices have been developed for collecting solar energy and turning it into electricity. In addition to supplying energy to residential buildings and companies, it is widely used in agriculture (for temporary lighting of premises, pumping water, preventing the formation of ice on the ponds where animals consume water, heating the barns for the animals to keep warm.

\section{The theoretical part}

Nowadays, ecotourism amounts about $20 \%$ of world tourist market providing service for millions of people every year at the international level. At present, ecotourism is the fastest growing segment of tourism industry with annual growth rates of $10 \%$ to $30 \%$ bringing billions of dollars to the state budget every year [2]. Except the positive economical aspect, uncontrolled tourism activity demonstrates such negative environmental impacts as atmospheric air quality decrease, soil erosion, water resources exhaustion, poorly cleaned discharges of sanatoriums and tourist and hotel complexes, noise pollution, unorganized sources of solid wastes of consumption, excessive loads on the ecosystem, forcing wild animals to migrate from their usual habitat, etc.

Air pollution and noise pollution are mostly caused by the tourist transport: the number of air travel, bus and rail routes increases with the growth of the number of tourists. Transportation of tourists accounts for $60 \%$ of all air travels. It was calculated, that one transatlantic flight ejects the amount of carbon dioxide equal to the average emissions due to human life during the year (heating, lighting, car usage, etc.) [3, 5]. Often, tourist buses, especially in the hot summer or cold Christmas seasons, leave their engines turned on for several hours for the tourists returning from the tour to feel 
comfortable inside the transport. Noise pollution from airplanes, cars, buses and also such recreational vehicles as snowmobiles or hydrocycles cause stress in wildlife [4]. This provokes their migration/escape away from the source of noise, and also significantly reduces the number of offspring.

The tourism industry consumes significant amounts of drinking water to satisfy the domestic needs of visitors as well as to ensure the functioning of pools and take care of the territory of the tourist establishments. At the same time, practically no recycling and clearing of the water is carried out before discharging. This can lead to water shortage and water resources degradation, in particular to the generation of large amounts of sewage.

Land resources which include minerals, fertile soils, forests, water objects and wildlife areas suffer from anthropogenic activities of tourists. From the moment of active demand for tourist objects, the construction of recreational complexes which provoke degradation of land resources has also grown. For the construction of one such object, deforestation is carried out in the allocated territory, which destroys the ecosystem in this place. Then construction begins, noise of which is a stress factor for wildlife. The construction and development of the infrastructure of tourist facilities usually include mining of sand, stones, other building and finishing materials, which causes erosion, landslides, change of the channel of small rivers. Construction of ski resorts and hotels often requires clearing of forest lands. Coastal wetlands are drained and built up in the absence of more suitable sites for the construction of tourist facilities and infrastructure. These actions can cause serious disruptions to the local ecosystem, even long-term degradation.

Forests often suffer from unorganized tourism because of deforestation for firewood. For example, according to UNEP, during a single mountain trip a group of tourists use $4 \div 5 \mathrm{~kg}$ of wood per person per day [5]. In the areas with high concentration of tourism activity there is another problem - the clogging of the territory and the significant accumulation of solid waste. Incorrect waste management schemes are an unexpected source of soil and surface water pollution.

Even tourist trails are dangerous for the environment. Trampling down the trails leads to reduction in biodiversity, since it is enough to step on the plant only once, so that it perishes. In tightly trampled soil the rainwater and air exchange get worse, the depth of freezing increases, the plant layer is destroyed, the tops of the trees dry up and the natural regeneration of the ecosystem degrades.

Scientists warn that like any other form of tourism, environmental tourism attracts visitors to isolated and remote areas that often cannot support such massive human activities. But there is a possibility of introducing insects, fungi and bacteria that are not typical of the area. The carriers of these parasites may have immunity to these diseases. Instead, for typical locals, this can turn into a global catastrophe and even lead to the destruction of ecosystems [6].

Exactly such negative factors lead to the creation of so-called ecological hotels - complexes which will take care not only of healthy rest of tourists but also of the environment. With the development of the ecological ideology promotion, organizers of the hotel industry recognized the negative impact of their activities on the environment and initiated measures to minimize this influence. A successful combination of an artificially created architectural ensemble with the surrounding landscape helps to harmoniously place eco-hotels in nature protection zones. Political acceptability, social responsibility and ecological environment will ensure sustainable development and balance between quality and quantity in tourism promotion.

Ecological hotel is an ecologically certified dwelling that can improve the environment minimizing its own negative impact on it. Usually, eco-hotels are located in ecological zones. They are built from environmentally friendly construction materials, use renewable sources for energy supply, introduce organic nutrition and waste management programs, etc.

In order to get the status "ecological", all hotels need to pass certification by independent authorities or the state in which they are located. Eco-hotels should, as a rule, respond to such criteria [7]:

- ecological stability;

- orientation towards the protection of the environment;

- increase in income of the country because of safe ecotourism usage;

- support of companies that produce eco-products (local natural food products, organic textiles - cotton, wool, flax), at the state level;

- use of renewable energy sources (solar or wind energy);

- energy saving lighting;

- use of environmentally safe vehicles;

- recycling of purified water which can be used for washing the area, irrigation of gardens and planting greenery.

There are many types of certificates ranging from free of charge to expensive. Expensive certificates require a third-party auditor for the analysis and comprehensive inspection of nature protection activities. Some certificates work well for all types of activity while others do not. For example, Trip Advisor offers free certification based on the poll, and LEED 
certification is only meaningful for construction projects of new hotels and full reconstruction projects.

Many countries, using the standard management of nature use 14001(1991), created their own standards of eco-certification. Eight most popular green certificates are listed below. The list is not complete, but it includes companies that enjoy the highest global recognition. They are: Trip Advisor Green Leaders; ENERGY STAR (USA, 1999); LEED (Leadership in Energy and Environmental Design, USA, 1994, subsequently extended to America and Europe); Green Globe (USA, Canada, United Kingdom); TUI (Touristic Union International, Germany, 2002); Green Seal (USA, 1989); Audubon Green Lodging (USA, 1987).

Green Key Global, the International Hotel Program for Environmental Certification of Hotel (Foundation for Environmental Education project, Denmark) entered the hotel industry market of Ukraine in 2011. This is a graded hotel marking system which is defined by 12 Criteria and estimated by 1 to 5 keys depending on their level of compliance with the program (5 keys is the highest score). The most rigorous criteria include [8] eco-management, energy conservation, water conservation, solid waste management, hazardous waste management, indoor air quality, public information, infrastructure construction, land use and environmental management.

\section{Experimental part}

Object of research: Derenivska Kupil sanatorium complex located in the tract of Derenivka (village Nizhnie Solotvyno, Uzhgorod district, Transcarpathian region) (see Fig. 1). For the first time, the Derenivka tract was mentioned in archival documents in 1582. During the 4-th century Derenivka was a part of six different states. Currently, the apartment hotel has 44 rooms. The maximum number of guests is 130 people. Usually the hotel is filled about $50 \%$, depending on the season. Water resources or rather mineral thermal springs which are related to silicon thermal springs are considered to be the peculiarity of the territory where the Derenivska Kupil sanatorium complex is located. They are available only within the limits of the Transcarpathian deflection in places with high geothermal background. The solubility of silicon acid in thermal waters increases significantly. Preferably, these waters are at a depth of $80-660 \mathrm{~m}$. At the general chloride-sodium composition mineralization of water varies within 1-3 $\mathrm{g} / \mathrm{l}$ to brines. The temperature rises from 23 to $56{ }^{\circ} \mathrm{C}$ at the outlet. The content of silicon acid is $50-130 \mathrm{mg} / \mathrm{l}$. The reserves of thermal silicon water according to preliminary estimation are not less than $6000 \mathrm{~m}^{3} /$ day.

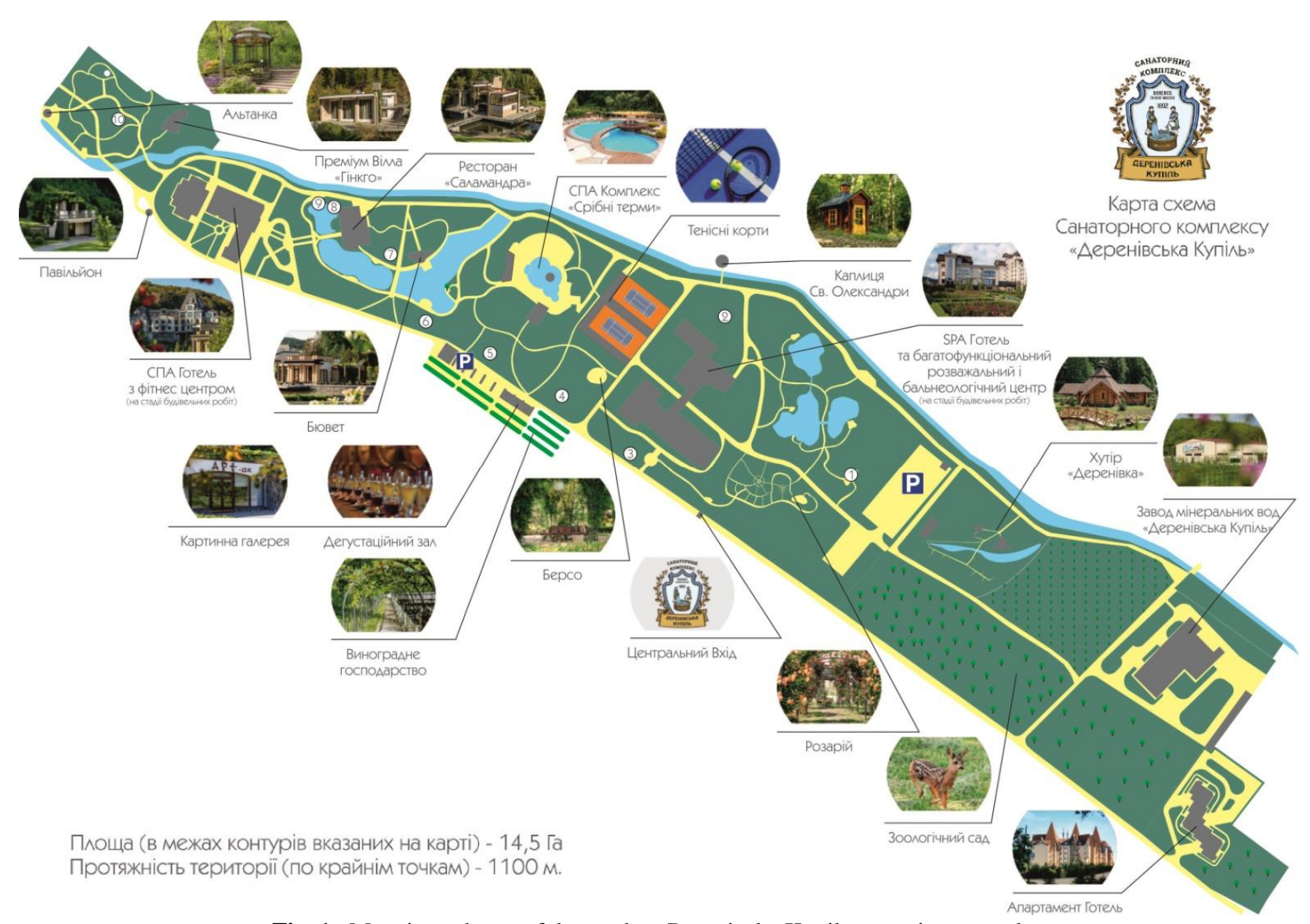

Fig. 1. Mapping scheme of the modern Derenivska Kupil sanatorium complex 
The purpose of the research was to make calculation and selection of components for the solar power plant. It is planned to connect this power plant to the general electricity grid, and in case of excess production of the energy, the station will be able to sell surplus to the state under the socalled "green tariff". In the case of a lack of electricity, for example, in the long period of gloomy weather, on the contrary, it will consume from the main electricity grid. This will be the most important event for the transfer of the renewable energy consumption of the apartment-hotel of the Derenivska Kupil sanatorium complex during the preparation for the Green Key certification.

Investigation methods: analytical (data analysis (quantity and capacity) of electricity consumption by all household equipment located in the rooms of the Derenivska Kupil Hotel). Research on the efficiency of the model network of solar power station was carried out in the computer laboratory of the Department of Ecology and Sustainable Nature Management of Lviv Polytechnic National University.

\section{Test Rest}

At the market there are 3 types of solar cells:

thin-film photocell, polycrystalline photocell and monocrystalline silicon photocell.
First of all it is necessary to mount the systems that control the heating and air conditioning of the rooms. This control system should be able to take into account the changes in the seasons and locally control the heating / cooling of the rooms that are used permanently. When installing solar panels, it is necessary to take into account some factors that can affect the efficiency of the solar panels. These factors include the angle of inclination of the panels, their location and quality. The factors that affect efficiency but which people can not influence are: time of the year, the amount of insulation, climate and cloudiness [9]. Also, their cost is a negative factor that prevents the widespread distribution of solar panels.

The amount of energy consumed depends on a season. Thus, in the summer, electricity consumption during the month is $4050 \mathrm{~kW}$ (about $130.5 \mathrm{~kW} /$ day), and in winter it is almost twice as high $-9550 \mathrm{~kW}$ (about $318.5 \mathrm{~kW} /$ day). Table 1 shows the average solar radiation in Uzhgorod district according to NASA data $\left(\mathrm{kWh} / \mathrm{m}^{2}\right.$ per day). In hours, the average sunshine is 1926 hours/year [10].

Table 1

Average monthly indicator of solar radiation in Uzhgorod

\begin{tabular}{|c|c|c|c|c|c|c|c|c|c|c|c|c|c|}
\hline months & $\underset{\Xi}{\overparen{\Xi}}$ & 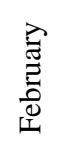 & 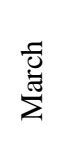 & $\frac{\bar{Z}}{\bar{z}}$ & $\stackrel{\vec{\Xi}}{\Sigma}$ & $\stackrel{\varrho}{\Xi}$ & $\underset{\Xi}{\Xi}$ & 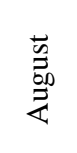 & 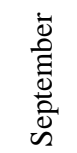 & $\begin{array}{l}\overline{8} \\
0 \\
0 \\
0 \\
0\end{array}$ & $\begin{array}{l}\dot{\bar{D}} \\
\text { है } \\
\text { Dे } \\
\text { Z }\end{array}$ & 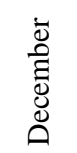 & 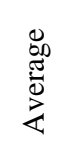 \\
\hline Uzhhorod & 1.13 & 1.91 & 3.01 & 4.03 & 5.01 & 5.31 & 5.25 & 4.82 & 3.33 & 2.02 & 1.19 & 0.88 & 3.16 \\
\hline
\end{tabular}

The average annual electricity consumption is $\approx 70000 \mathrm{~kW}$. In order to provide an eco-hotel with $70000 \mathrm{~kW}$ of electricity, it is necessary to choose a solar power station with the capacity of $70 \mathrm{~kW}$.

For the calculation, a polycrystalline solar panel of the AS 280P-60 brand, with the capacity of $280 \mathrm{~W}$, and the size of $1650 \times 992 \times 40 \mathrm{~mm}$ [11] was chosen. One of the main advantages of this panel is a low coefficient of temperature losses. When heating such photo-module at $1{ }^{\circ} \mathrm{C}$, the nominal power decreases by $0.39 \%$, as opposed to the usual photo-modules where this index reaches $0.4-0.5 \%$.

So, to calculate the number of panels, we need to divide the power of the system into power panels:

$$
\text { 70000: } 280=250(\text { panels AS 280P-60) }
$$

The capacity of the inverter was selected depending on the system power. The advantage of an Altek inverter is that it is capable of handling the overload up to $30 \%$ for direct current. Moreover, it allows supplying the network with the power greater than nominal. Altek Network Inverter works with efficiency up to $98.2 \%$. In this case 2 inverters are required, since the number of inputs will be 12. For each Altek inverter a Wi-Fi monitoring device is installed. One module is used for one inverter.

The solar panels are planned to be installed on the roof of the hotel. For mounting it is necessary $\approx$ $500 \mathrm{~m}^{2}$ of roof surface. The panels are fastened with aluminum fasteners calculated for each panel. The panels will be located to the south and the angle of the inclination is $45^{\circ}$. The cable was calculated $120 \mathrm{~m}$ for $10 \mathrm{~kW}$ of installed capacity. Table 2 lists the required parts for a $70 \mathrm{~kW}$ power station. The elements of the solar power station were selected from the Internet catalogue [11].

According to the data presented in Table 3, it can be assumed that the annual planned generation of electricity will be $83930 \mathrm{~kW}$. 
Elemental composition of the solar power station

\begin{tabular}{|c|c|c|c|}
\hline & Name & Value, USD & Q-ty \\
\hline & $\begin{array}{l}\text { Solar panel polycrystalline AS280P-60, power } 280 \text { Watts. } \\
\text { Dimensions } 1650 \times 992 \times 40 \mathrm{~mm} \text {. } 118250\end{array}$ & 118 & 250 \\
\hline & $\begin{array}{l}\text { Inverter network ACRUX-30K }(30-39 \mathrm{~kW}) \text {. } \\
\text { Number of entrances - 6. MPPT range } 480-800 \mathrm{~V} \text {. Maximum } \\
\text { current at MRPT-26A. }\end{array}$ & 3650 & 2 \\
\hline & $\begin{array}{l}\text { Device for monitoring Altek inverters using Wi-Fi technology. } \\
\text { One module is used for one inverter. }\end{array}$ & 150 & 2 \\
\hline & Fastening to the slope, aluminum & 40 & 250 \\
\hline & Solar cable $6 \mathrm{~mm}$ & 1,5 & 800 \\
\hline & Cable connector MS4 pair $6 \mathrm{~mm}$ & 3 & 50 \\
\hline & Grounding & 200 & 1 \\
\hline & Additional materials, shields, glue, corrugation & 190 & 1 \\
\hline & Installation work & 6000 & 1 \\
\hline & Start-up and adjustment works of the inverter and systems & 200 & 1 \\
\hline & Overhead and shipping costs & 200 & 1 \\
\hline
\end{tabular}

Table 3

Amount of the energy generated per month, $\mathrm{kW}$

\begin{tabular}{|c|c|c|c|c|c|}
\hline January & February & March & April & May & June \\
\hline 1820 & 3000 & 6825 & 9375 & 11860 & 12250 \\
\hline July & August & September & October & November & December \\
\hline 12300 & 11150 & 7300 & 4540 & 2200 & 1310 \\
\hline
\end{tabular}

With the help of IBC SOLAR which has developed its own solar power efficiency calculator [12], we calculate the efficiency of the above presented model of the solar station for 20 years of using solar panels. First, you need to specify the exact location of the object (Derenivska Kupil eco-hotel) and the overall dimensions of the roof (Fig. 2) where the solar panels are planned to be placed. The width, length of the roof, angle of inclination and direction must be noted. The total area of the roof reaches approximately $500 \mathrm{~m}^{2}$. Roof angle of inclination is $45^{\circ}$, with direction to the south.

The next step is to choose the quantity of solar panels. According to calculations, 250 panels are needed for efficient energy production. Next (Fig. 3), enter the parameters of the amount of electricity 
consumed for the specified hotel, namely the average electricity consumption of the hotel; current price of electricity (it is necessary to calculate in US dollars, since the Hryvnia is not available in the calculator); the average annual increase in electricity prices and supply compensation.
Analysis of calculations of the efficiency after 20 years of using this power station is presented in Fig. 4. To the left of the figure, the efficiency of using the solar station without the use of the solar energy storage unit is indicated, and the efficiency with the storage unit is indicated on the right.

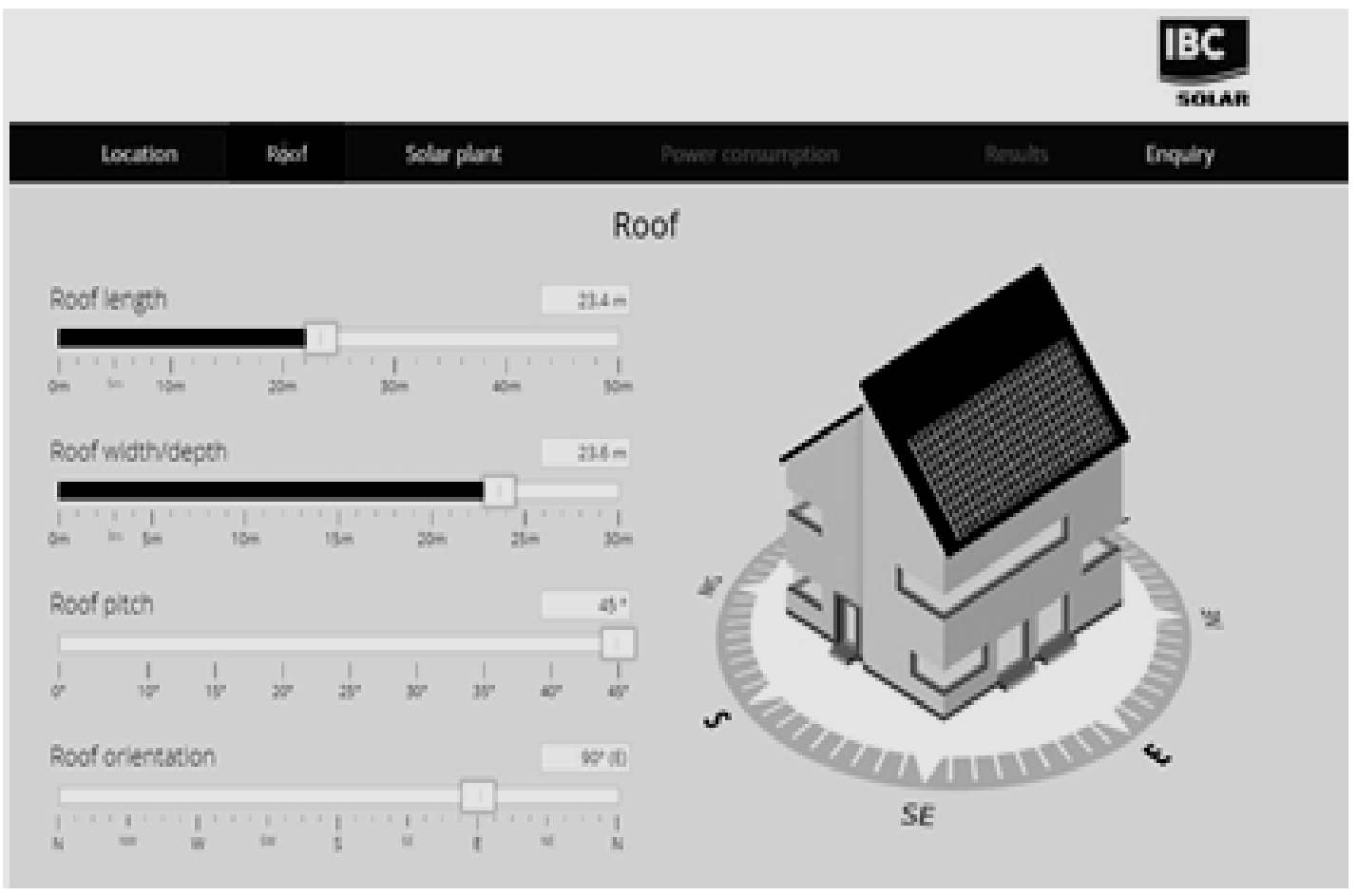

Fig. 2. Introduction of the overall dimensions of the roof

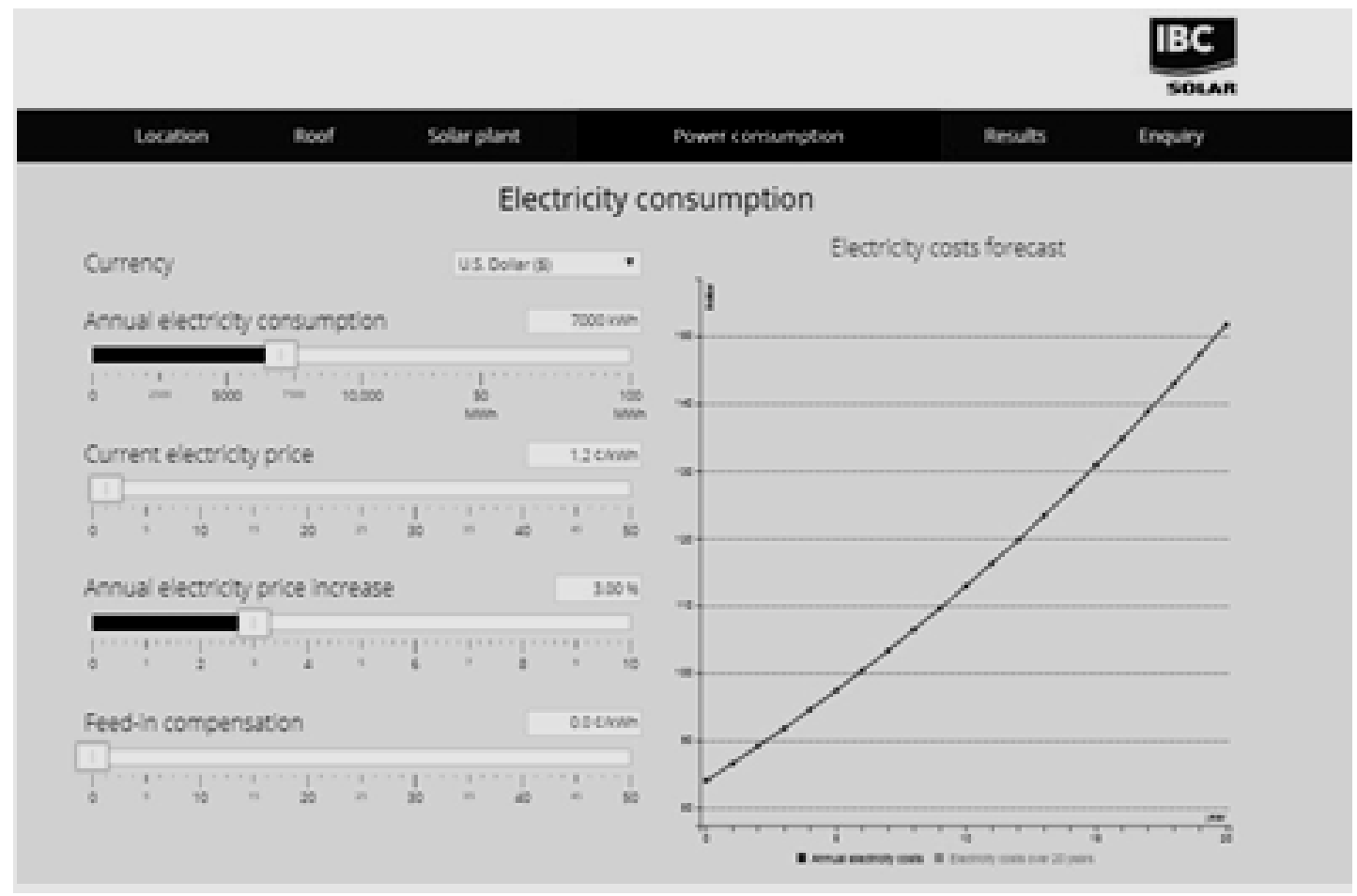

Fig. 3. Parameters of electricity consumption. The graph shows the forecast of electricity costs by 2030 


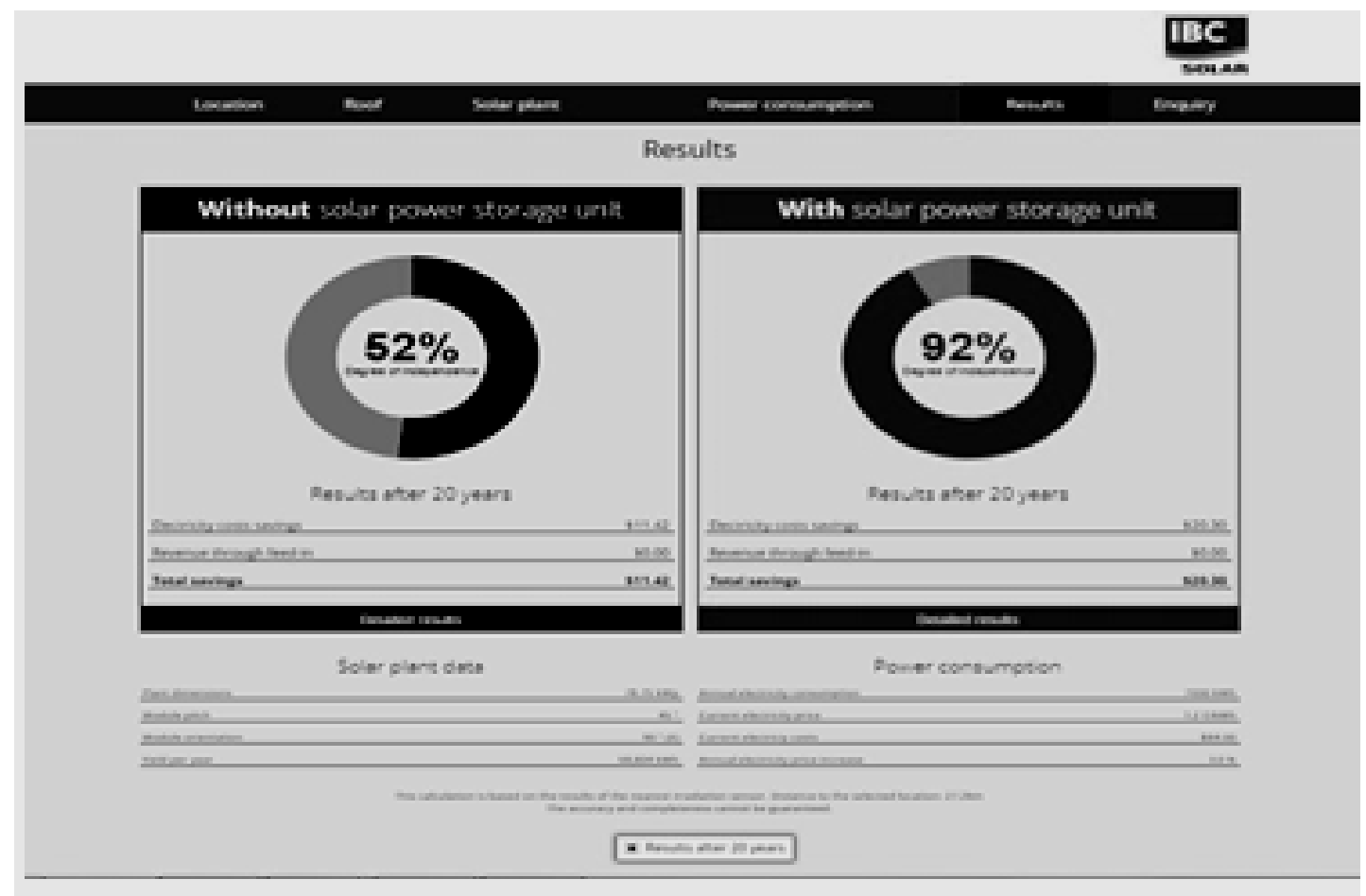

Fig. 4. Results of the efficiency of the solar power plant

According to the results of the efficiency analysis, on average for a year, with the use of the solar energy storage unit, the selected SES will provide $92 \%$ of the hotel with its own electricity.

\section{Conclusions}

Indicators of energy efficiency give the hotel facility an opportunity to compare its business with others. The article presents the results of the selection of the components and the principle calculation of the elements of the network solar power plant, as well as the data on the monthly electricity generation of the selected Solar Power Plant. The results of the research can be used to introduce the latest technological solutions that will reduce the energy use by the apartment-hotel of the Derenivska Kupil sanatorium complex and facilitate the successful passage of the Green Key environmental certification.

\section{References}

[1] UNEP and UNESCO (1993). Managing Tourism in World Heritage Sites.

[2] Kubai D. Ekolohichni aspekty suchasnoho rozvytku turyzmu. // Visnyk Lviv. Un-tu. Seriia mizhnarodni vidnosyny. 2008. Vypusk No. 24. S. 142-146.
[3] Kyfiak V. F. Orhanizatsiia turystychnoi diialnosti v Ukraini // Chernivtsi: Knyhy-KhKhI. 2003. 300 s.

[4] Dmytruk O. Iu. Ekolohichnyi turyzm: Suchasni kontseptsii menedzhmentu i marketynhu// K.: Alternatyva, 2004. $192 \mathrm{~s}$.

[5] Prohrama OON z navkolyshnoho seredovyshcha (UNEP) - 2001// Rezhym dostupu: https://www.gdrc.org/ uem/eco-tour/envi/index.html

[6] IUCN The World Conservation Union (1996). Tourism, Ecotourism and Protected Areas.

[7] Poniattia i kryterii eko-hoteliv // Rezhym dostupu: https://www.ukessays.com/essays/tourism/criteria-for-ecohotel-tourism-essay.php.

[8] Milinchuk O. V. Perevahy ekolohichnoi sertyfikatsii hoteliv v Ukraini. // Menedzhment v innovatsiinomu rozvytku ekonomiky: problemy ta perspektyvy. S. 322-323

[9] Dudiuk D. L., Mazepa S. S. Netradytsiina enerhetyka: osnovy teorii ta zadachi. Navchalnyi posibnyk. - Lviv: Mahnoliia 2006. 2008. 188 c.

[10] Pryroda Zakarpatskoi oblasti / Za red. K. I. Herenchuka. Lviv: Vyshcha shkola. Vyd-vo pry Lviv. un-ti, 1981. $156 \mathrm{~s}$.

[11] Onlain-kataloh internet-mahazynu "Ekotekhnik"// Rezhym dostupu: https://ekotechnik.ua/ukr/oborudovanie/

[12] Onlain-kalkuliator rozrakhunku soniachnykh elektrostantsii IBC SOLAR // Rezhym dostupu: https://powercalculator. ibc-solar.com/. 